\title{
THE INFLUENCE OF PROFITABILITY, LIQUIDITY, AND DEBT TO THE DIVIDEND PAYOUT RATIO IN MANUFACTURING COMPANY (LISTED IN INDONESIAN STOCK EXCHANGE FROM 2008-2010)
}

\author{
Putri Kartika Sari \\ Universitas Islam Indonesia, Yogyakarta \\ Sigit Handoyo \\ Universitas Islam Indonesia, Yogyakarta \\ e-mail: sihando@yahoo.com
}

\begin{abstract}
This research analyzes the influence of profitability, liquidity, and debt to dividend payout ratio in manufacturing companies in Indonesia. The samples consist of 102 companies listed in Indonesian Stock Exchange during the period of 2008-2010. This research tests three hypotheses related to the influence of profitability, liquidity, and debt toward the dividend payout ratio (DPR). Data obtained were analyzed by using multiple regression analysis. The results of this research indicate that: (1) profitability ratio (ROI) has positively significant influence to dividend payout ratio. (2) Liquidity ratio $(Q R)$ does not significantly influence to dividend payout ratio. (3) Debt ratio (DER) does not significantly influence to dividend payout ratio.
\end{abstract}

Keywords: profitability, liquidity, debt, Dividend Payout Ratio (DPR), manufacturing company.

\begin{abstract}
Abstrak
Penelitian ini bertujuan untuk menganalisis pengaruh profitabilitas, likuiditas, dan utang terhadap rasio pembayaran dividen dalam perusahaan-perusahaan manufaktur di Indonesia. Sampel terdiri dari 102 perusahaan yang terdaftar di Bursa saham Indonesia selama periode tahun 20082010. Penelitian ini menguji tiga hipotesa yang berkaitan dengan pengaruh profitabilitas, likuiditas, dan utang terhadap rasio pembayaran dividen (DPR). Data yang diperoleh dianalisis dengan menggunakan analisis regresi. Hasil dari penelitian ini menunjukkan bahwa: (1) profitabilitas rasio (ROI) memiliki pengaruh positif dan signifikan terhadap rasio pembayaran dividen. (2) rasio likuiditas (QR) tidak berpengaruh terhadap rasio pembayaran dividen. (3) Rasio hutang (DER) tidak berpengaruh atas rasio pembayaran dividen.
\end{abstract}

Kata kunci: profitabilitas, likuiditas, utang, rasio pembayaran dividen (DPR), manufaktur perusahaan.

\section{BACKGROUND}

Economic global crisis has begun in 2008. The effects of economic crisis were influenced most of the countries in the world including Indonesia. Indonesia as the countries which still have the trust from local and foreign investors settle their position with providing solid monetary and fiscal policy to support the local company. According to Jensen (2000), investors will consider about the risk and return when they decide to invest their money. The company can be run well if company can maximize the satisfaction of stakeholder. Many company modifying their strategy to increase efficient and effective business conduct in order to survive. The degree of efficient and effectiveness of company's strategic and performance can be seen in the financial statement. Financial statement analysis is the main source in identifying the company's performance.

Thus this research has some purposes. The first purpose to know whether profitability which is represented by ROI have positive influence to the dividend payout ratio, because the profitability has some functions for instance, as the representation of company's capability in generating income to settle the debt, as the main resource to provide fund for expan- 
sion and as prediction for company going concern. If earning after tax increase, it will increase the ROI. In the end, the increasing of ROI will increase dividend payout ratio and vice versa (Kadir, 2010). The second purpose is to know whether liquidity which is represented by QR have positive influence to the dividend payout ratio. Liquidity becomes the representation of company's capability in settling the shork term debt in settlement date. If companies have capability to manage their asset in generating the income and have good liquidity, it will encourage company to increase the dividend payout ratio. The third purposes is to know whether debt which is represented by DER have negative influence to dividend payout ratio, because DER will show the capability of company in settling the long term debt and the debt will guarantee by the owner's equity. Company will make priority to settle the obligation from the external parties before fulfill the right of stockholders in the liquidation term.

\section{REVIEW OF RELATED LITERATURE}

Investors who invest their money in capital market have to consider about the market and economics condition. Investment in capital market will be affected by fluctuation which can cause gain or loss for the investor. To adjust the condition, investors will demand higher return to bear the related risk. The return can be in the form of dividend and capital gain. The investors will get dividend if they hold the stock for long-term and intend to maintain or increase their ownership in a particular company. The investors also can earn capital gain through selling the stock. Capital gain or loss is the different between the stock selling price and purchasing price.

According to Kusumaningrum (2002) and Stephen (2005), the functions of financing involve three major decisions. They are Investment Decision, Financing Decision and Dividend Decision.

\section{Investment Decision}

The investment decision is the most important decision that firm has to take. Capital investment is the allocation of capital to be invested to several proposals to get benefit in the future. Consequently, their expected rate of return and risk has to be evaluated before decision is made. Expected rate of return and risk are factors affecting the firm's market valuation. In addition, a firm must manage the existing assets efficiently and must consider where to invest the asset. Company must consider the good portfolio method in making investment decision and not to put all of the capital in one investment.

\section{Financing Decision}

The second major decision of the firm is the financing decisions. Here, the financial managers focus in determining the best financing mix or capital structure. If a company can change its total value by varying its capital structure, an optimal financing mix can be achieved and in the end market price per share can be maximized.

\section{Dividend Decision}

The third important decision of the firm is its dividend policy. The dividend policy includes the percentage of earnings paid to stockholders in cash dividends, the consideration about economic condition, stock dividends, stock splits, and stock repurchasing. The dividend - payout ratio determines the amounts of retained earnings in the firm and must be evaluated to be able to achieve the objective of maximizing shareholder's wealth.

Dividend policy is related to the sha ring earning. It is about making decision whether net income will be distributed to the stockholders as dividend or treated as retained earnings. Retained earnings are one of important financial sources which can be used for financing the company's growth (Hashemijoo, 2012). Types of financing can be divided into two. They are internal financing and external financing. Internal financing is the fulfillment of company's financial needs by using its sources; usually it is taken from the retained earnings. Then, external financing is the fulfillment of company's financial needs by using external sources. External sources can come from the owner of the company or equity financing, selling bond, debt from creditor, debt from supplier, debt from bank, and etc.

Previous research about the influence of the profitability, liquidity and debt toward dividend payout policy has been done by Purbosari, 2006. The research explained that prof- 
itability, liquidity, and debt have positive influence to dividend payout policy. That research has taken the data from public companies which listed in Indonesian Stock Exchange and has distributed their dividend from 2001 until 2004. The other research which related with this research is done by Puspita in 2009. Her thesis developed the formula with more consideration about the influence of cash ratio, growth, firm size, ROA, DTA, and DER. That research has taken the data related to with public company which listed in Indonesian Stock Exchange from 2005 until 2007.

\section{RESEARCH METHODOLOGY}

\section{Population and Sample}

Population is the whole elements which will be source in making conclusion. Sample is a part of population which will be the source of research and will be the representative of population. Population which will be used in this research are all of manufacturing companies, listed in Indonesian Stock Exchange from period 2008 until 2010 and published in Indonesian Capital Market Directory (ICMD). The sample will be taken by using purposive sampling method. It means that sample will not be randomly selected. Sample will be taken by using some considerations and certain criteria (Widarjono, 2007). This research will use some criteria's to filter the sample. They are: 1) Manufacturing company which paid the dividend in period 2008 until 2010 in a row. 2) Financial company, banks, and insurance company are excluded from the sample. 3) Companies used as sample in this research are those with complete data, and provide information related to Dividend Payout Ratio, Quick Ratio, Return on Investment, and Debt to Equity Ratio.

\section{Research Data}

The research instruments utilized in this research were taken from literature in the library, internet, the stock exchange corner in FE UII, and information published by Indonesian Capital Market Directory (ICMD).

\section{Research Variable Dependent variable}

Dividend payout ratio (DPR) is the dependent variable in this research. Dividend payout ratio is the percentage of company's profit which will be distributed to stockholders (Booth, 2008). The formula of DPR is:

Dividend Payout Ratio $=\frac{\text { Dividen Per Share }}{\text { Earnings Per Share }}$

\section{Independent variable}

This research will use three independent variables, they are Return on Investment (ROI), Quick Ratio (QR), and Debt to Equity Ratio (DER).

\section{Return on Investment (ROI)}

Return on investment is a comprehensive ratio which can measure the capability of a company to produce profit and to measure the effectiveness of a company in using and managing the company's resources used in the operational activities (Booth, 2008). The formulation for ROI is the net profit will be divided by total asset. ROI also can be substituted by ROA, because basically ROI will measure how much the return from the total asset (company's resources) used in operational activities.

Return on Investment $=\frac{\text { Earning After Tax }}{\text { Total Asset }}$

\section{Quick Ratio (QR)}

Quick ratio is the financial ratio which will measure the liquidity of a company in fulfilling the short term obligation or in the other words it measures company's capability in covering their short term debt by using its current asset except its inventory (Booth, 2008). The formula for Quick ratio is:

Quick Ratio $=\frac{\text { Current Asset }- \text { Inventeroy }}{\text { Total Asset }}$

\section{Debt to Equity Ratio (DER)}

Debt to Equity Ratio is the financial ratio which will measure the capability of company in fulfilling the long term obligation or in the other words it shows company's capability in covering their total liability by using their own capital (Booth, 2008). The formula for DER is:

Debt to Equity Ratio $=\frac{\text { Total Liability }}{\text { Owner's Equity }}$ 


\section{Data Ankysis Methodology}

According to Widarjono (2007), regression model which is used in from Ordinary Least Square/OLS will give unbiased result (Best Linier Unbias Estimator /BLUE). This condition will happen if the data fulfill some criteria's: 1) Nonmulticoleniarity, it means that there is no perfect or closed to perfect relationship among independent variables used in the regression model. 2) Homoscedacity, it means that the variance among independent variables is constant. 3) Nonautocorrelation, it means that the influence of variables will not be affected from previous year's and current year's data.

\section{Normality Test}

Normality test has a purpose to determine whether the dependent variable and independent variables in the regression model have a normal distribution or not. The data distribution must be normal or close to normal in order to create a good regression model. This study will use Normal PP Plot graphs test. If the pattern of data distribution which is represented by dots, around the diagonal line and the direction suit with diagonal line of Normal PP plot graph, the regression model has met the assumption of normality and vice versa.

\section{Multicollinearity Test}

Multicollinearity test is a test that must be passed by the model. Its purpose is to know the correlation between independent variables. The good regression model must not have correlation relationship among the independent variables.

According to Widarjono (2007), Multicolinearity can be measure using VIF (Variance - Inflating Factor). If VIF $<10$, the multicolinearity problem does not exist, it means that there are no significant correlations between independent variables in regression model and vice versa.

\section{Heteroscedascity Test}

According to Widarjono (2007), heteroscedascity test aims to test whether the regression model occurs in the condition where the variance from one residual observation to another observation is constant or not, this condition also can be called by homoscedascity. In the condition where the variance from one residual to another observation is different, it is called as heteroscedascity.

This study will use Spearman Rank Correlation Test. In the Spearman Rank Correlation test, if the significant value (Sig, (2tailed) correlation of each independent variable with residual value is greater than the level of significance research $(\alpha)$, it can be concluded that there is no heteroscedascity in the research model. The level of significance applied in this research is $\alpha=5 \%$. This means that if the significant value (Sig. (2-tailed) correlation of each independent variable with the residual value is less than $5 \%$, it can be concluded there is heteroscedascity in the model. if the significant value (Sig. (2-tailed) correlation among each independent variable residual value is greater than $5 \%$ then it can be concluded that there was no heteroscedascity.

\section{Autocorrelation Test}

Autocorrelation is a correlation between the members in the range of time or between spaces for cross section data. This study will use Durbin - Watson Test in testing whether the regression model has autocorrelation relationship or not, with the criteria as seen on table 1 . DW is Durbin - Watson value, which can be found by using Durbin - Watson Test in the SPSS 20. The dL and dU can be found from Durbin - Watson statistic tables.

Table 1: Criteria of Durbin - Watson Test

\begin{tabular}{ll}
\hline \multicolumn{1}{c}{ The Criteria } & \multicolumn{1}{c}{ The Conclusion } \\
\hline $\mathrm{DW}<\mathrm{dL}$ & There is positive autocorrelation \\
$\mathrm{dL}<\mathrm{DW}<\mathrm{dU}$ & Cannot be concluded whether there is autocorrelation or not \\
$\mathrm{dU}<\mathrm{DW}<(4-\mathrm{dU})$ & There is no autocorrelation \\
$(4-\mathrm{dU})<\mathrm{DW}<(4-\mathrm{dL})$ & Cannot be concluded whether there is autocorrelation or not \\
$\mathrm{DW}>(4-\mathrm{dL})$ & There is negative autocorrelation \\
\hline
\end{tabular}




\section{Model Testing}

\section{Regression coefficient test prompt (F test)}

$F$ test is used to show the effect of variation of independent variables variation collectively to the dependent variable. Significant of independent variables to the dependent variable is showing the probability value from $F$ test of each independent variable at test level $\alpha=5 \%$. To conclude the acceptance or rejection of $\mathrm{H} 0$ and $\mathrm{H} 1$, here are the conditions that we need to consider: 1) If the probability is smaller than $\alpha$, then $\mathrm{H} 0$ is rejected and $\mathrm{H} 1$ is accepted, which means that the independent variables have a significant influence on the dependent variable. 2) If the probability is larger than $\alpha$, then $\mathrm{H} 0$ is accepted and $\mathrm{H} 1$ is rejected, which means that the independent variable has no significant effect on the dependent variable.

\section{Partial regression coefficient test (t Test)}

$\mathrm{T}$ test was used to test the significance of the partial effects of independent variables on the dependent variable. Significant of independent variables to the dependent variable is showing the probability value from the $t$ test of each independent variable at Sig. level $\alpha=5 \%$. So, the condition to accept or reject $\mathrm{H} 0$ and $\mathrm{H} 1$ are as follows: 1) If the probability is less than $\alpha$ then $\mathrm{H} 0$ is rejected and $\mathrm{H} 1$ is accepted, which means that the independent variables have a significant influence on the dependent variable. 2) If the probability is bigger than $\alpha$ then $\mathrm{H} 0$ is accepted and $\mathrm{H} 1$ is rejected, which means that the independent variable has no significant effect on the dependent variable.

\section{Hypotheses of This Research}

Hypotheses of this research are formulated as following:

H1: Profitability has positive influence toward dividend payout ratio in a company.

$\mathrm{H} 2$ : Liquidity has positive influence on dividend payout ratio in a company.

H3: Debt has negative influence on dividend payout ratio in a company.

\section{DATA ANALYSIS}

\section{Classical Assumption Test}

Classical assumption test is used to detect whether the model in this research is fulfilling the requirement to be valid model or not. Some requirement tests that need to be done are normality test, multicollinearity test, heteroscedascity test and autocorrelation test.

\section{Normality test}

Normality test has purpose to determine whether the independent variables and dependent variable in the regression model have normal distribution or not.

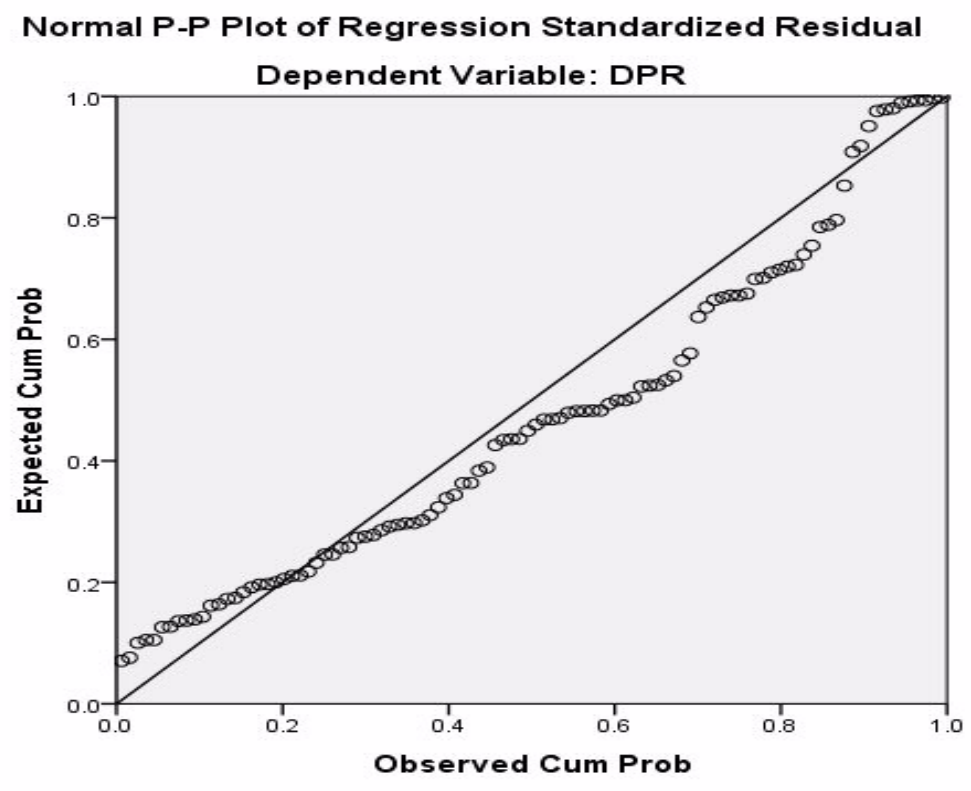

Figure 1 
Based on the figure 1 Normal PP Plot (Normal PP Plot of Regression Standardized Residual), it shows that the pattern of data points distribution is around the diagonal line and the direction suits with diagonal line of Normal PP Plot. Based on the pattern of data point's distribution on the normal PP Plot graph, it can be concluded that the regression model meets the assumption of normality.

\section{Multicoliniearity Test}

Multicollinearity test has purpose to determine whether there is significant correlation between independent variables in regression models or not. If the model has multicolinearity problem, the model should reduce the variables or replace them with other variables. The table 2 below will show the result from multicolinearity test.

According to Widarjono (2007), multicolinearity can be measured by using VIF (Variance - Inflating Factor). If VIF $<10$, it means that there is no significant correlation between independent variables in regression model and vice versa. Based on Multicollinear- ity test, table 2 shows that the VIF of ROI (1.238), QR (1.075), and DER (1.308) is less than 10 (VIF< 10). So, it can be concluded that the regression model have no multicollinearity problem.

\section{Heteroscedascity Test}

Heteroscedacity test has purpose to determine whether the result of regression model in some variances from residual observation was constant (homoscedascity) or different (heteroscedascity). This study will use Spearman Rank Correlation to test the regression model. The result of Spearman Rank Correlation test is shown in the table 3 .

The level of significance $(\alpha)$ applied in this research is $5 \%$. Based on the table 3 above, we can summarize the value of each residual variable in the table 4.

From the table 4, the significant value (Sig. (2 -tailed) of each residual is greater than the level of significance $(\alpha)$. Therefore, it can be concluded that there is no heteroscedascity in the research model.

Table 2: Multicollinearity Test

\begin{tabular}{|c|c|c|c|c|c|c|c|c|}
\hline & \multirow{2}{*}{ Model } & \multicolumn{2}{|c|}{$\begin{array}{l}\text { Unstandardized Co- } \\
\text { efficients }\end{array}$} & \multirow{2}{*}{$\begin{array}{c}\begin{array}{c}\text { Standardized Co- } \\
\text { efficients }\end{array} \\
\text { Beta } \\
\end{array}$} & \multirow{2}{*}{$\mathrm{T}$} & \multirow{2}{*}{$\begin{array}{c}\text { Sig. } \\
\text { Tolerance }\end{array}$} & \multicolumn{2}{|c|}{ Collinearity Statistics } \\
\hline & & $\mathrm{B}$ & Std. Error & & & & Tolerance & VIF \\
\hline \multirow{4}{*}{1} & (Constant) & .262 & .060 & & 4.397 & .000 & & \\
\hline & ROI & .006 & .003 & 199 & 1.833 & .037 & .808 & 1.238 \\
\hline & QR & -.016 & .010 & -.154 & -1.526 & .130 & .930 & 1.075 \\
\hline & DER & -.017 & .025 & -.076 & -.685 & .495 & .764 & 1.308 \\
\hline
\end{tabular}

Table 3: The Result of Spearman Rank Correlation Test

\begin{tabular}{|c|c|c|c|c|c|c|}
\hline \multicolumn{7}{|c|}{ Spearman Correlations } \\
\hline & & & ROI & QR & DER & $\begin{array}{c}\text { Unstandardized } \\
\text { Residual } \\
\end{array}$ \\
\hline \multirow{12}{*}{ Spearman's rho } & \multirow{3}{*}{ ROI } & Correlation Coefficient & 1.000 & $.200^{*}$ & $-.560^{* *}$ & -.110 \\
\hline & & Sig. (2-tailed) & & .043 & .000 & .269 \\
\hline & & $\mathrm{N}$ & 102 & 102 & 102 & 102 \\
\hline & \multirow{4}{*}{ QR } & Correlation Coefficient & $200^{*}$ & 1.000 & $-.402^{* *}$ & -.098 \\
\hline & & Sig. (2-tailed) & .043 & & .000 & .328 \\
\hline & & $\mathrm{N}$ & 102 & 102 & 102 & 102 \\
\hline & & Correlation Coefficient & $-.560^{* *}$ & $-.402^{* *}$ & 1.000 & .002 \\
\hline & \multirow[t]{2}{*}{ DER } & Sig. (2-tailed) & .000 & .000 & & .980 \\
\hline & & $\mathrm{N}$ & 102 & 102 & 102 & 102 \\
\hline & \multirow{3}{*}{$\begin{array}{l}\text { Unstandard- } \\
\text { ized Resid- } \\
\text { ual }\end{array}$} & Correlation Coefficient & -.110 & -.098 & .002 & 1.000 \\
\hline & & Sig. (2-tailed) & .269 & .328 & .980 & \\
\hline & & $\mathrm{N}$ & 102 & 102 & 102 & 102 \\
\hline
\end{tabular}

*. Correlation is significant at the 0.05 level (2-tailed).

**. Correlation is significant at the 0.01 level (2-tailed). 
Table 4: Significant Value of Each Residual Variables Compared to Alpha

\begin{tabular}{lcccc}
\hline Variabel & Unstandardized Residual $(\mathrm{sig})$ & alpha $(\alpha)$ & Condition & Conclusion \\
\hline ROI & 0.269 & 0.05 & $>$ alpha & \\
QR & 0.328 & 0.05 & $>$ alpha & There is no \\
DER & 0.980 & 0.05 & $>$ alpha & heteroscedacity \\
\hline
\end{tabular}

\section{Autocorrelation Test}

Autocorrelation test has purpose to determine the correlation between the members in the range of time or between spaces for cross section data in the regression model. This research will use Durbin - Watson test to analyze the existence of autocorrelation in the research model. The result form Durbin - Watson test can be seen in the table 5. Basd on the criteria for Durbin - Watson test, the summary can be presented in the table 6 .

Based on the table 5 , the value of DW is 1.951 , the value of DW is in the range between 1.73 and 2.27. So, it indicated that the regression model does not have autocorrelation problem.

\section{Model Testing}

\section{Regression Coefficient Test Prompt (F test)}

$\mathrm{F}$ test is used to test the suitability of regression model by showing the effect of variation of independent variables collectively to the dependent variable. This test used significant level $\alpha=5 \%$. The result of $F$ test can be seen in the table 7 .

Based on the result of regression model in the table 7, the value of F is 2.397 with Sig. value of 0.033 . Since, the significant level between dependent variable and independent variables is 0.033 , which is less than $\alpha=5 \%$, it means that there are significant influences existed between dependent variable and independent variables. In the other words, ROI, QR, and DER simultaneously influence DPR.

\section{Partial Regression Coefficient Test (t test)}

$\mathrm{T}$ test was used to test the significance of the independent variables partial effects on the dependent variable.

Table 5: Result of Durbin - Watson Test

\begin{tabular}{lccccc}
\hline \multicolumn{6}{c}{ Model Summary $^{\mathbf{b}}$} \\
\hline Model & $\mathrm{R}$ & $\mathrm{R}$ Square & $\begin{array}{c}\text { Adjusted R } \\
\text { Square }\end{array}$ & $\begin{array}{c}\text { Std. Error of the Es- } \\
\text { timate }\end{array}$ & Durbin-Watson \\
\hline 1 & $.261^{\mathrm{a}}$ & .068 & .040 & .21448147 & 1.951 \\
\hline $\begin{array}{l}\text { a. Predictors: (Constant), DER, QR, ROI } \\
\text { b. Dependent Variable: DPR }\end{array}$ & & & & \\
\end{tabular}

Figure 6: Boundary of Autocorrelation with Durbin - Watson Test

\begin{tabular}{ccccc}
\hline $\begin{array}{c}\text { Autocorrelation } \\
(+)\end{array}$ & Unclear result & No Autocorrelation & Unclear result & $\begin{array}{c}\text { Autocorrelation } \\
(-)\end{array}$ \\
\hline 0 & $\mathrm{dL}$ & $\mathrm{dU}$ & $4-\mathrm{dU}$ & $4-\mathrm{dL}$ \\
& 1,61 & 1,73 & 0 & 2,27 \\
\hline
\end{tabular}

Table 7: The Result of F test

\begin{tabular}{rlrrrrr}
\multicolumn{8}{c}{ ANOVA $^{\mathrm{a}}$} \\
\cline { 3 - 5 } & Model & Sum of Squares & Df & Mean Square & F & Sig. \\
\hline \multirow{2}{*}{1} & Regression & .331 & 3 & .110 & 2.397 & $.033^{\mathrm{b}}$ \\
& Residual & 4.508 & 98 & .046 & & \\
& Total & 4.839 & 101 & & & \\
\hline
\end{tabular}
a. Dependent Variable: DPR
b. Predictors: (Constant), DER, QR, ROI 
Based on the result of regression model in the table 8, it can indicate the relationship among ROI, QR, DER, and DPR which can be presented in the formula below:

$$
\begin{aligned}
\mathrm{DPR}= & 0.262+0.006(\mathrm{ROI})-0.016(\mathrm{QR})- \\
& 0.017(\mathrm{DE})+\varepsilon
\end{aligned}
$$

This regression model has constant at 0.262 , it means that if the ROI, QR, and DER are zero, the DPR will be 0.262 .

Then, based on the result in table 8 , it can indicate that ROI has positive influence on DPR with Beta 0.199, QR has negative influence on DPR with Beta -0.154, and DER has negative influence on DPR with Beta -0.076 . Since, the significant level of ROI is 0.037 , which less than $\alpha=0.05$, so ROI has significant influence to DPR.

\section{The Effect of Independent Variables toward Dependent Variable}

\section{Profitability}

In the previous chapter of this research, the hypotheses regarding the influence of profitability towards the dividend payout ratio are as follows.

H0: Profitability (ROI) does not have positive influence toward dividend payout ratio in a company.

H1: Profitability (ROI) has positive influence toward dividend payout ratio in a company.

Based on the result in table 9, we can indicate that return on investment (ROI) has positively significant influence toward the dividend payout ratio which is represented by Beta of ROI (0.199) and the significant level (P value) at 0.037 . Hence $P$ - value of ROI is 0.037 which is less than $\alpha=0.05$, so we can accept $\mathrm{H} 1$ and reject $\mathrm{H} 0$. It means that the increasing of ROI will increase the DPR (Dividend Payout Ratio), because the decision related to DPR is based on the return on investment earned by the company.

The positive sign will represent the capability of the company in managing the company's resources to generate profit and fulfill investor's expectation related to the company's development in the future. The increasing of earning after tax (EAT) will increase the position of ROI. It means that company can be ex- pected to be able in paying the dividend to stockholders in the date of payment and stockholder can have expectation about the increasing performance of the company in the future. The result of this research that shows the positive influence of ROI which is ROI will increase if earning after tax which came from managing the company resources (asset) is increasing. The increasing of ROI will cause the increasing of DPR as the base of dividend distribution. It is the basic policy in distributing dividend to stockholders in order to increase stockholder's welfare.

The result of this research that shows the positive influence of ROI is also supported by Purbosari (2006) and Puspita (2009) who concluded that the profitability which is represented by ROI has positive significant influence toward dividend payout ratio. If the company can earn high profit, it will be able to increase the distribution of dividend to stockholder.

\section{Liquidity}

In the previous chapter of this research, the hypotheses regarding to the influence of liquidity to the dividend payout ratio are as follows.

H0: Liquidity $(\mathrm{QR})$ does not have positive influence toward dividend payout ratio in a company.

$\mathrm{H} 2$ : Liquidity $(\mathrm{QR})$ has positive influence toward dividend payout ratio in a company.

Based on the result in table 9, we can indicate that Quick Ratio (QR) has negative influence toward dividend payout ratio. This condition is represented by the Beta of QR ($0.154)$ and the significant value $(\mathrm{P}-$ value $)$ at 0.130 . Hence $\mathrm{P}-$ value of $\mathrm{QR}$ is 0.130 which is bigger than $\alpha=0.05$, so we will accept $\mathrm{H} 0$ and reject $\mathrm{H} 2$. It means that Quick Ratio (QR) does not significantly influence to dividend payout ratio (DPR).

The result of this research in which shows the negative influence of QR reflects that manufacturing companies in Indonesia have some considerations in increasing shortterm liability during 2008 until 2010. This condition can be influenced by external factors.

According to Direktorat Riset Ekonomi dan Kebijakan Moneter Bank Indonesia (2008), the existence of global crisis influences the 
economics condition around the world. The examples of global crisis's impacts are the increasing of oil price and inflation. Economic condition is also affected by free market. All of those factors encouraged many companies to do their best to survive from bankruptcy. During this condition, investors were worrying about the economic condition while the companies must be able to do their daily operation. So, many companies decided to increase shortterm liability. Logically, if companies increase their liability, it will affect the decreasing of DPR because part of the profit that will be distributed to the stockholders as dividend will be retained by the company in order to secure the company's position in settlement date. The companies must have optimism that they can settle their liability using the profit of that year.

According to Penyelenggaraan Pemerintahan dan Pembangunan Daerah (2009), the government also gave their best effort to rearrange the interest level of Bank Indonesia in order to decrease the interest level of other bank and supporting the local companies' growth in Indonesia. In the end of January 2009, Bank Indonesia has decreased the BI's interest level from 8.75 percent to 7.5 percent. The aim was to motivate and to help the public companies to survive in the economic global crisis. The decreasing of interest level will encourage the companies in taking debt to the bank in order to run their operation activities with low interest level. This condition can be proofed by the facts of debt growth from $26.4 \%$ to $30.7 \%$ in 2008 . Company's commitment to settle is also improving, as it can be seen from the decreasing of Non-Performing Loan (NPL) from $4.1 \%$ in 2007 to $3.2 \%$ in 2008 .

The result of $\mathrm{QR}$ is different from the previous research which is done by Purbosari (2006). She stated that QR has positive sign to dividend payout ratio. It means that the companies have good liquidity at that time. The result of this research that shows the negative influence of $\mathrm{QR}$ may differ from the others because of economics condition regarding the economics global crisis in 2008. It is also because of different sample taken as the source of this research.

\section{Debt}

Hypotheses used in testing debt to equity ratio are as follows:
H0: Debt (DER) does not have negative influence toward dividend payout ratio in a company.

H3: Debt (DER) has negative influence toward dividend payout ratio in a company.

Based on the result in table 9, DER has negative influence to dividend payout ratio (DPR). This condition can be represented by the value of Beta (-0.076) and the significant value $(\mathrm{P}-$ value $)$ at 0.495 . Hence $\mathrm{P}-$ value of DER is 0.495 which is bigger than $\alpha=0.05$, so we will accept $\mathrm{H} 0$ and reject $\mathrm{H} 3$. It means that DER does not significantly influence to dividend payout ratio (DPR)

This result is different from the result of the previous research. According to Purbosari (2006), the increasing of debt which is represented by DER will not influence the DPR because most of the public companies in Indonesia use their profit for two purposes. First, the profit is allocated for the retained earning which is used to develop and support the growth of the company itself. Second, the profit is allocated as the source of dividend distribution to stockholders.

Although a company has high level of debt, it does not mean that they stop to pay dividend for their stockholders because, maintaining the satisfaction of stockholders is really important for a company. The company must be able to use their resources wisely. By using the residual cash available at the end of the period, management could satisfy the shareholders by paying the dividend and at the same time try to settle its debt.

However, the result of this research that shows the negative value of DER was supported by Puspita (2009), because of the global crisis' influence many companies have to reconsider their decision. This condition happened because many companies have two aims, to provide fund for settling the liability and distribute dividend to stockholders. Unfortunately, economic global crisis push the companies to make wise decision because even though their debt was high, they must consider to stockholder's satisfaction. The alternative taken by the companies is they will give dividend even though it was small. The rest of the available profit will be used for settling the liability and establishing retained earnings to expand the business, because they have to consider their 
going concern while trying to satisfying the stockholders. The company's survival is repress According to Prawironegoro (2006), in fact, the amount of dividend distribution is related to the decision of General Meeting of Stockholders. Every company has their own considerations whether they want to use the profit to increase retained earning which will be used in developing and expanding their company or they want to increase the satisfaction of the stockholders by increasing the stockholder's welfare.

In The General Meeting of Stockholders, the company's management will give suggestion to the stockholders to increase the retained earnings in order to develop and support the growth of company. However, stockholders have their own consideration related to benefit cost ratio before they invest their capital.

Stockholders will agree to receive small dividend and increase the retained earning if they are sure that the return from the profit which will be invested in form of retained earning has higher return on investment (ROI). However, if stockholders are not sure about the company's future and stockholders feel that the return from their investment cannot cover the risk, they will ask for bigger dividend payment.

There are some supporting considerations for the stockholders before taking decision about dividend payout ratio in The General Meeting of Stockholders. The first is management's suggestion. Management has a role as the party who know the company's condition, business condition, and economics condition related to the amount of DPR (Dividend Payout Ratio). The management's suggestion consists of some information about previous, present, and predicted data and will be presented in the analytical form. The second is the corporation's law which regulates and protects the rights of minority stockholders related to the earnings after tax distribution.

The third is liquidity condition, the stockholders must be aware of the company's condition. If the company do not have liquidation problem, it will be able to pay the dividend. Meanwhile, if the company has liquidation problem, it will have dividend liability or it might pay the dividend in form of shares. It means that the stockholders must invest their dividend in order to save the company.
The fourth is company's decision, to develop and expand their business. This condition required dividend payout ratio to be small because an ideal company's growth must be supported by fund which comes from retained earnings and there should be no liability increasing.

The fifth one is the settlement of longterm liability. If company has higher long-term liability, stockholder must consider in decreasing dividend payout ratio in order to increase the retained earning which will be used for the settlement of long-term liability.

\section{CONCLUSION AND RECOMMENDATION}

Based on research that has been done regarding the influence of profitability (ROI), liquidity (QR), and debt (DER) to the dividend payout ratio (DPR), the conclusions are as follows: 1) The partial influence of each factors toward dividend payout ratio is as follows: a) Profitability (ROI) has positive influence to dividend payout ratio (DPR) significantly. The increasing of ROI will be followed by the increasing of DPR and vice versa. b) Liquidity (QR) has negative influence to dividend payout ratio, but it does not influence significantly. c) Debt (DER) has negative influence to dividend payout ratio, but it does not influence significantly. 2) Profitability (ROI), liquidity (QR), and Debt (DER) have significant influence to the dividend payout ratio (DPR) simultaneously.

However, there are some limitations which encourage the researcher to give suggestion that: 1) The next researcher may use other than manufacturing company, because Indonesia has many sectors which can be chosen as the investment sectors. 2) The next researcher is going to add other variables to their research which have an influence on dividend payout ratio. Next researcher also should consider about the external factors, for instances, economics condition, the price of stock, and etc.

\section{REFERENCES}

Booth, L. and W. S. Cleary. 2008. Introduction to Corporate Finance. Ontario: John Wiley \&Son.

Direktorat Riset Ekonomi dan Kebijakan Moneter Bank Indonesia. 2008. Outlook Ekonomi Indonesia 2008-2012: 
Integrasi Ekonomi ASEAN dan Prospek Perekonomian Nasional. Retrieved November 9, 2011, from http://www.gaikindo.or.id/download/in dustry-policies/k-bank-indonesia/OEI2008-2012.pdf

Hashemijoo, M., A. M. Ardekani and N. Younesi. 2012. The Impact of Dividend Policy on Share Price Volatility in the Malaysian Stock Market. Journal of Business Studies Quarterly. 4(1).

Jensen, M. C. 2000. Value Maximization and The Corporate Objective Function. Harvard Business School, USA. Retrieved November 9, 2011, from http://www.hbs.edu/research/facpubs/w orkingpapers/papers2/9900/00-058.pdf

Kadir, A. 2010. Analisis Faktor-Faktor yang Memperngaruhi Kebijakan Dividen pada Perusahaan Credit Agencies Go Public di Bursa Efek Jakarta. Jurnal Manajemen dan Akuntansi. April Vol. 11, No.1.

Kusumaningrum, A. 2002. The Profitability Analysis of PT. Indofood Sukses Makmur Tbk. Unpublished bachelor thesis, Universitas Islam Indonesia, Yogyakarta.

Penyelenggaraan Pemerintahan dan Pembangunan Daerah. 2009. Retrieved No- vember 10, 2011, from www.bappenas.go.id/get-fileserver/node/7621/

Prawironegoro, D. 2006. Manajemen Keuangan. Jakarta: Diadit Media.

Purbosari, Y. N. 2006. Pengaruh Profitabilitas, Likuiditas, dan Hutang pada Perusahaan Public yang Terdaftar di Bursa Efek. Unpublished bachelor thesis, Universitas Islam Indonesia, Yogyakarta.

Puspita, F. 2009. Analisis Faktor-Faktor yang Mempengaruhi Kebijakan Dividen Payout Ratio. Universitas Diponegoro, Semarang. Retrieved Oktober 7, 2011, from http://eprints.undip.ac.id/17411/1/FIRA _PUSPITA.pdf

Stephen W. P. and L. J. Gitman. 2005. The Interactions between the Investment, Financing, and Dividend Decisions of Major U.S. Firms. Accounting Review. Retrieved November 9, 2011, from http://onlinelibrary.wiley.com/doi/10.1 $111 / \mathrm{j} .1540-$ 6288.1991.tb00388.x/references

Widarjono, A. (2007). Ekonometrika: Teori dan Aplikasi untuk Ekonomi dan Bisnis ( $2^{\text {nd }}$ ed.). Yogyakarta: Ekonisia. 